\title{
The Preparation of the Standards for Junior College Libraries
}

ITHE STANDARDS FOR JUNIOR COLLEGE 1 Libraries were prepared by the Committee on Standards, ACRL. Its members are: Felix E. Hirsch, Trenton State College, chairman; Helen M. Brown, Wellesley College; Donald O. Rod, Iowa State Teachers College; Ruth E. Scarborough, Centenary College for Women; Orlin C. Spicer, Morton Junior College; Norman E. Tanis, Henry Ford Community College; Helen M. Welch, University of Illinois. Lottie M. Skidmore, Joliet Township High School and Junior College, served as consultant, representing the Junior College Library Section.

Efforts toward drawing up standards go back to 1930 when the Junior College Libraries Round Table, the predecessor of the section, was founded. The $A L A$ Bulletin for August 1930 (XXIV, 296-97) contained a junior college "Measuring Stick," the first forerunner of the present standards. One of those who drew up that first brief document, Ermine Stone, soon after presented a commendable set of standards in her book The Junior College Library (ALA, 1932). The next major study was undertaken when Mary H. Clay (now Mrs. E. R. Lloyd), chairman of the section in 1946-47, collected detailed data about standards from state and regional chairmen. At the ALA Conference in Los Angeles, 1953, Ruth E. Scarborough, then chairman of the section, organized a panel discussion on the need for printed standards to strengthen the junior college library in all its aspects. A committee on standards was appointed with Ruth Bradley as chairman. The new section chairman, Lottie M. Skidmore, assigned it a dual task: to prepare a statement of standards which would be submitted to the membership for approval and to collect material suitable for an ACRL Monograph. Many suggestions were gathered, partly via the JCLS Newsletter. Elizabeth Neal, the next chairman of the section, compiled these proposals and had them discussed at two meetings, but there remained disagreement on the issue of quantitative versus qualitative standards. That issue seemed resolved at the ALA Conference in Miami Beach, 1956, when the section accepted the revised standards. Work began on the proposed ACRL Monograph about the junior college library in all its aspects and including especially the standards; Catherine Cardew, Briarcliff College, served as editor, and Mrs. Katherine Brubeck, Orlin Spicer, and Ruth E. Scarborough as contributors. Before the monograph reached the printing stage, the ACRL Board in June 1959 reviewed the whole project, and particularly the standards of 1956 , and decided to turn them over to the ACRL Committee on Standards to bring them up to date.

The committee went immediately to work. In November 1959 it met for a two-day work session in Chicago. A complete understanding was reached and a draft prepared. It paralleled the $A L A$ Standards for College Libraries and embodied the wishes of the junior college librarians consulted. This draft was submitted to leaders of the library profession for their critical comments. The advice of many presidents and deans of junior colleges was secured. The executive secretaries of the American Association of Junior Colleges, the National Commission on Accreditation, and the six regional accrediting agencies expressed themselves strongly in favor of the draft. Many valuable suggestions were incorporated in the text and a definitive draft was prepared in January 1960. At its meeting on January 29, 1960, the Board discussed the standards and approved them unanimously. 


\section{Standards for Junior College Libraries}

$\mathrm{T}$ THESE STANDARDS are designed to provide a guide for the evaluation of libraries in American two-year colleges. These institutions offer a great diversity of programs; many of them are terminal, others prepare for eventual transfer to four-year colleges. Included in this group of two-year colleges are junior colleges primarily concerned with the liberal arts and limited in their vocational aims; community colleges endeavoring to serve in their area a variety of educational purposes by a combination of programs; and technical institutes emphasizing vocational aspects in their curricula. For the sake of convenience, the term "junior college library" is used throughout to describe libraries in all these institutions.

\section{Functions of the Junior College L.IBRARY}

The junior college library has manifold responsibilities. First of all, it must provide the resources needed to meet the curricular demands of the institution. It must have a rich and up-to-date collection of books, periodicals, recordings, and other educational materials necessary for inspiring teaching. Beyond meeting this objective, the junior college library should bring strong intellectual stimulation to both faculty and students. It should help the faculty to keep abreast of the progress of scholarship. It should introduce students to the heritage of Western civilization, provide them with a view of the non-Western world, and instill in them that enthusiasm for great books from which will spring the life-time habit of good reading.

Fulfillment of this complex mission will require a highly competent staff of sufficient size and capable of serving along the following major lines of endeavor: The junior college library is the center of curricular materials for the institution and a focal point for the cultural life on campus. It serves as an important teaching agency, providing bibliographic advice to the faculty and giving instruction, both formal and informal, in the use of books and libraries to the students during freshman o:izntation
This document was prepared by the ACRL Committee on Standards, Felix $E$. Hirsch, Chairman.

as well as throughout their college careers. It furnishes reading guidance and reference service in many ways and stimulates interest in good books through displays, booklists, discussion programs, etc. It assists in the counseling program by providing occupational and vocational materials for the use of students and the guidance staff. Finally, the junior college library often functions also as a center of community affairs in connection with adult education programs or similar efforts for the cultural benefit of many citizens.

The standards laid down in this document must always be interpreted in the light of the aims and needs of the institution of which the library is a part.

\section{Structure ANd Government}

The librarian is usually appointed by the chief administrative officer of the college. He should be directly responsible to him for the management of the library.

If the institution's board of control has a committee on the library, its duties and authority should be clearly defined, and the advisory relationship of the librarian to the committee should be stated.

The librarian should be consulted by the chief administrative officer on the budgetary needs of the library, prior to final decisions by the institution's board of control. Any change in budget direction or any other administrative ruling affecting the welfare of the library should be made only after careful discussion with the librarian.

Academic matters, on the other hand, demand close cooperation with the dean of instruction. Membership of the librarian on the curriculum committee or academic policy committee is advisable to develop unity of purpose between classroom and library. The librarian should have at least department head status.

The professional library staff should be 
appointed by the chief administrative officer on the recommendation of the librarian, and should be directly responsible to the librarian. The librarian should plan the internal structure of the library administration with clear-cut job descriptions for each staff member. Frequent consultation with staff members on library policies and procedures will promote an atmosphere of democracy in the library and strengthen the staff morale.

As a rule, there should be a faculty library committee. It should be appointed by the chief administrative officer or elected by the faculty. It should include representatives of the various academic divisions of the college and consist of both senior and junior members of the faculty, chosen carefully for their demonstrated interest in the library beyond their own departmental concerns. The librarian may serve as chairman or secretary. The committee functions in an advisory capacity to him and acts as a connecting link between the faculty as a whole and the library. It should not concern itself with details of library administration.

In many institutions it will also be helpful to have a student library committee. It serves as a liaison between the student body and the library, and presents suggestions on student-library relationships. The committee should work closely with the librarian who may use it as a sounding board for new ideas in developing a more effective library program.

The librarian should keep statistical records which elucidate the use, services, and acquisitions of the library. Such records should follow good form as required by the Library Services Branch of the Office of Education of the United States Department of Health, Education and Welfare, regional accrediting associations, and the Association of College and Research Libraries. An informative and well conceived annual report to the administrative officers of the college will be an effective instrument to publicize appropriately the accomplishments of library service as well as the librarian's ideas for its future development.

\section{BUDGET}

The size of the budget inevitably determines to a large extent the scope and the effectiveness of the junior college library program. The library's holdings, the type of college it serves, the size of the faculty and student body, the variety and spread of subject fields covered, and the extent to which the college frowns on textbook teaching and encourages the use of supplementary readings are factors which influence budget needs.

The library budget should be determined in relation to the total budget of the institution for educational and general purposes, but the amount to be allocated to the library should be squarely based upon a program of optimum library service in support of the junior college's goals. The execution of the library program as it is outlined in these standards normally requires a minimum of 5 per cent of the total educational and general budget. ${ }^{1}$ This minimum percentage ${ }^{2}$ is for a well established library with an adequate collection. It would have to be augmented if there is a rapid increase in the student body or in course offerings; it would again need to be increased if the library is responsible for an audio-visual program. The library budget for a newly organized junior college should be considerably higher than 5 per cent. The figure might be determined by establishing rather precise acquisition goals over an initial period of several years.

Experience shows that a good junior college library usually spends at least twice as much (or more) for salaries as it does for books and periodicals. Allocation of funds within the total library budget should be the responsibility of the librarian. He should assume the leadership to promote a balanced library program, to correct deficiencies in the collections, and to plan for meeting future needs.

\section{STAFF}

The library should have a broadly educated and well qualified staff of professional librarians. Being responsible for the effective operation of the library and for the interpretation of its collections, they must be able

\footnotetext{
1 The Office of Education in the U. S. Department of Health, Education and. Welfare defines "educational and general" as operating funds used to defray expenditures for administration, instruction, research, extension services, plant operation and maintenance, and organized activities related to instructional departments. This percentage is based on the consensus of many junior college librarians consulted as well as on an analysis of the junior college library statistics made available to the committee prior to their publication by $\mathrm{Col}$. lege and Research Libraries in its issue of January 1960.
} 
to perform a great variety of important services. Professional members of the staff in a junior college library should hold a graduate library degree and possess also, wherever needed, a credential to meet state certification laws. They should have a rich subject background.

The size of the staff will depend upon such major factors as the number of students and faculty the library serves, the number of hours the library is open, the type of curriculum or curricula offered, the teaching methods prevailing at the junior college, the arrangement of the library rooms, the nature of the services required, and the rate of growth of the collection. A professional librarian should be on duty at all times the library is open for full service.

Two professional librarians are the minimum number required for effective service in any junior college with an enrollment up to 500 students (full-time equivalent). In addition, there should be at least one nonprofessional library staff member. The larger the institution, the more appropriate it will be to employ a higher proportion of non-professional staff. Great care should be taken that professional staff members do not spend their time doing work that is essentially clerical, because this is not only wasteful but also demoralizing. If the library administers the audio-visual services, additional competent staff should be provided. A junior college library for which technical processes are performed by a central agency can function effectively with a proportionally smaller staff.

Students cannot replace full-time nonprofessional assistants, nor should student hours be evaluated as equivalent to nonprofessional hours even though students, under proper supervision, may be used effectively for a variety of tasks.

Professional librarians should have faculty status, preferably including faculty rank and titles identical to those of the teaching staff. Faculty status should involve such considerations as tenure, sick leave, liberal vacations, sabbatical leave, retirement benefits, and inclusion in the faculty salary scale. It follows that librarians should be expected to meet the same requirements for graduate study as do members of the teaching faculty, according to the established promotion poli- cies at their institution. Continued graduate work, whether in library science or another area, should be encouraged; it may well lead to a second or third Master's degree rather than to a Ph.D. degree.

Participation of the library staff in the educational program of the institution should include-as indicated earlier-instruction in the use of the library, advice to faculty members on bibliographic matters, preparation of communications on library facilities, and membership on college committees, especially those concerned with academic problems.

\section{The Library Collection}

\section{A. Books and Periodicals}

The collection of a junior college library, consisting of books, periodicals, pamphlets, maps, micro-publications, archival and audio-visual materials, should be selected and organized so as to promote and strengthen the teaching program in all its aspects. It should also seek to aid faculty members in their professional and scholarly growth.

The holdings of the junior college library should include a generous amount of carefully chosen works presenting our common heritage. They should be supplemented by a wide variety of modern books in the major fields of knowledge, books that should be both timely and enduring. The collection should include in particular many works of high caliber which will arouse intellectual curiosity, counteract parochialism, and help to develop critical thinking. Liberal provision should also be made for stimulating recreational reading. The library holdings should offer a challenge to all elements represented in the student body and assist them in their intellectual growth.

The reference collection must be strong; it should be up to date and broad in its coverage. It should include standard reference works in all major fields of knowledge, several periodical indexes, a wide selection of outstanding subject bibliographies, and the authoritative book lists for junior college libraries. ${ }^{3}$

3 Mary N. Barton, Reference Books: a Brief Guide for Students and Other Users of the Library (4th ed. Baltimore: Enoch Pratt Library, 1959), is an excellent recent short list of major reference works. It should be carefully examined; its annotations offer valuable suggestions.

Junior college librarians will also benefit greatly 
Periodicals and newspapers constitute an invaluable source of reference for material on many subjects. They should be selected by the librarian, with the assistance of the faculty. The periodical subscription list should be well balanced. It should include titles of lasting reference value as well as journals helpful to the faculty or appealing to the young college readers. ${ }^{4}$ Periodicals of permanent significance should be bound or made available in microform.

The reading of newspapers is of increasing importance to students in an era of world-wide political and social changes.-Subscriptions should provide ample news coverage at the national, regional, and local level. Various political points of view should

from checking the following two basic lists, even though they are not up to date: Foster E. Mohrhardt, $A$ List of Books for Junior College Libraries (Chicago: ALA, 1937) and Frank J. Bertalan, Books for Junior Colleges (Chicago: ALA, 1954). Florida State University, under the direction of Dean Louis Shores, has begun to issue book and magazine lists for junior colleges, which are intended to supplement Bertalan's list. In addition, attention is called to the well balanced list issued by the Southern Association of Colleges and Secondary Schools, Commission on Colleges and Universities, The Classified List of Reference Books and Periodicals for College Libraries; edited by W. Stanley Hoole (3d ed.; Atlanta, Ga.: The Association, 1955). Useful suggestions for specific purposes may also be found in the Catalogue of the Lamont Library, Harvard College, prepared by Philip J. McNiff and members of the library staff (Cambridge, Mass.: Harvard University Press, 1953).

Librarians of junior colleges will be well advised to check also some authoritative shorter subject bibliographies such as The Concise Cambridge Bibliography of English Literature, 600-1950, edited by George Watson (Cambridge: University Press, 1958) and the Harvard List of Books in Psychology, compiled and annotated by the psychologists in Harvard University (2d ed.; Cambridge, Mass.: Harvard University Press, 1955). Also Louis $\mathrm{R}$. Wilson, The Library in College Instruction (New York: H. W. Wilson, 1951) contains many pertinent suggestions. Librarians in institutions stressing science and technology will find a reliable guide in Scientific, Medical and Technical Books Published in the U.S.A to December 1956, edited by R. R. Hawkins the U.S.A. to December 1956, edited

Holdings of indexes should not be limited to sets of Readers' Guide and International Index. Wherever the instructional program of the junior college makes a broader coverage desirable, if not essential, subscriptions to other indexes should be included such as Applied Science and Technology Index, Book Review Digest, Business Periodicals Index, Education Index, Engest, Business Periodicals Index, Education Index, EnTechnical Book Review Index, etc; the librarian should aim to subscribe at least to some of the iournals indexed there. Also files of abstracting journals such as Bio. logical Abstracts, Chemical Abstracts, and Psychological Abstracts will be great assets for reference purposes. Finally, the New York Times Index will answer many questions of readers and help locate materials, even if the library cannot yet afford to subscribe to the Neze York Times on microfilm.

4 Junior college librarians should have on their sub. scription list some outstanding foreign periodicals like The Economist, London, Manchester Guardian Weekly, Realites, Paris (English language edition), and the Times Literary Supplement, London, as a guard against provincialism. In general, subscriptions should be checked against such an authoritative compilation as Classified List of Periodicals for the College I-ibrary (4th ed., revised and enlarged by Evan Ira Farber; Boston: F. W. Faxon Company, 1957). be presented by the papers selected. Permanent availability of the files of a major newspaper on microfilm is highly desirable.

The stand of the American Library Association on the subject of censorship should be firmly adhered to by junior college librarians. The right of the librarian to provide books, periodicals, and other materials which present all sides of controversial issues cannot be disputed. Attempts at censorship should be resisted no matter how expedient it would be to comply. ${ }^{5}$

The following considerations will determine the size of the library collection: the breadth of the curriculum; the method of instruction employed; the number of students (full-time equivalent) and faculty; the demands of the faculty for research materials; the availability of other appropriate library resources; and the kind of student body served, i.e., residential vs. commuting students.

A two-year institution of up to $1,000 \mathrm{stu}$ dents (full-time equivalent) cannot discharge its mission without a carefully selected collection of at least 20,000 volumes, exclusive of duplicates and textbooks. ${ }^{6}$ Junior colleges with broad curriculum offerings will tend to have much larger collections; an institution with a multiplicity of programs may need a minimum collection of two or three times the basic figure of 20,000 volumes. The book holdings should be increased as the enrollment grows and the complexity and depth of course offerings expand. Consultation with many junior college librarians indicates that for most junior college librarians a convenient yardstick would be the following: the bookstock should be enlarged by 5,000 volumes for every 500 students (fulltime equivalent) beyond 1,000 .

Librarians, instructors, and administrators should study carefully the latest compilation of junior college library statistics. They

5 The fundamental position of the American Library Association has been stated in the Library Bill of Rights adopted in 1948. Recent lucid discussions of the subject of censorship include those by Robert B. Downs in American Library Annual and Book Trade Almanac 1959 (New York: R. R. Bowker, [1958], pp. 91-92 and Donald E. Strout in American Library \& Book Trade Annual 1960 (New York: R. R. Bowker, [1959]) pp. 129-32. Attention is also called to the collection of essays The First Frecdom: Liberty and Justice in the World of Books and Reading, edited by Robert B. Downs (Chicago: ALA, 1960).

$B$ This figure is based on the agreement of many junior college librarians consulter and on an analysis of recent statistics provided in College and Research Libraries. 
should measure the adequacy of their collections against the reported holdings of junior colleges of established excellence with similar curricula and enrollments. Junior college libraries with strong financial support, a vigorous faculty, and talented leadership will forge ahead of any minimum standards.

The traditional book collection will be supplemented and broadened by the judicious selection of government documents and the many useful pamphlets now available. Under no circumstances should junior college libraries limit their collections to books in print. Quality paperbacks, reproducing standard works long out of print, and new processes such as photo-copying, micro-texts, and microfilms should be imaginatively utilized. Finally, the strength and quality of the collection must not be impaired by excessive buying of duplicates and textbooks.

The following categories of library materials should be weeded and discarded: obsolete materials and editions; broken files of unindexed periodicals; unnecessary duplicates; old recreational periodicals which do not have permanent value; and worn out books, pamphlets, periodicals, and audiovisual materials. As far as possible, the weeding process should be undertaken in consultation with the faculty.

Gifts should be accepted only in case they add to the strength of the library collection and do not carry unreasonable restrictions. Administrators, faculty, and librarian should join in developing a policy which clearly defines what kinds of gifts are desirable for the institution and why it is important educationally to integrate them with the regular collection except in rare instances.

The library's collection should be fully organized for use. The main catalog of the library should serve as a union catalog for all collections of the library wherever housed. The catalog should follow the Library of Congress and American Library Association cataloging codes as standards. Materials should be classified according to an accepted scheme in general usage. Subject headings should be edited continually to keep the catalog abreast of modern developments. The catalog should also be constantly revised to keep it up to date in terminology.

\section{B. Audio-Visual Materials}

Audio-visual materials are an important part of modern instruction. They can play a major role in the learning process by supplementing books and other printed materials. They should be ordered, housed, and administered in the library unless another department on the campus is effectively executing this program. Audio-visual materials may include films, filmstrips, slides, tapes, recordings in music, drama, speech, and foreign languages. The same high standard of selection should be used as for books and other library materials. Faculty advice should be sought when needed.

If the audio-visual program is administered by the library, an additional trained staff member and an additional budget allotment should be provided. Whether or not these materials are housed in the building and controlled by the library staff, they should be properly indexed in the library catalogs where faculty and students can readily locate these materials.

\section{BUILDING}

The junior college library must be so housed as to provide adequate space for the book collection on open shelves, with a sufficient number of seats for readers adjacent to the shelves. The library, whether in a separate building or not, should be centrally located. Its atmosphere should be conducive to intellectual effort; that is, it should be quiet and pleasant, have fresh air and good lighting, and be kept at a comfortable temperature. Proper control of humidity and heat is also essential for the care of the collection.

The shelf capacity required in any library depends upon the size of the collection and its rate of growth. In general, new library quarters should provide for the expansion of the library over the same period with which the institution is concerned in its over-all planning. Any new library should be so located that its future expansion is possible. Housing must be provided for special materials such as current periodicals, maps, pictures, art books, films, records, tapes, archives, and microprint.

The number of seats required will be determined by such factors as the teaching methods prevailing in the college, the size 
of the enrollment, whether the student body is housed on the campus or is largely composed of commuters, and whether provision is made by the college for additional study areas elsewhere. It is suggested that seats in the library should be provided for at least 25 per cent of the student body, equated to full time. Colleges which anticipate a marked increase in enrollment in the near future will need to consider more generous seating.

Space must be provided for all the services of the library, including circulation and reference areas, exhibit space, audio-visual quarters, etc. The layout of the areas should be planned to require a minimum of staff supervision. Traffic through the library should be by well defined, adequate aisles which do not cross reading areas.

The work quarters should be planned for the efficient flow of work through the activities of ordering, cataloging, processing, binding preparation, and mending. Staff work areas should comprise at least 125 square feet of floor space per person. Provision should be made for expected growth of the staff.

The furniture in the library should be sturdy, comfortable, and attractive in design. It is recommended that the table space allotted to each reader measure at least three feet by two feet, whether in carrels or at larger tables. A variety of types of seating should be available in the library, including carrels, table seats, individual study desks, and comfortable chairs away from tables. Experience indicates that in planning new libraries, twenty-five square feet per reader is an acceptable standard, exclusive of stack space and of work areas.

\section{The Quality of The Service AND ITS Evaluation}

Because there are so many intangible factors involved, one of the most difficult tasks of librarianship is to determine the quality of library service. But the inherent difficulties in no way minimize the importance of attempting to discover the extent to which a given library is serving its clientele.

Statistical records maintained by the circulation department constitute one major source of information which may be useful in an evaluation of service, although in an open-shelf library these records give only a partial picture of the use of materials. However, if the per capita circulation of books on regular loan to students for two weeks or longer indicates an upward trend over a significant period of time, it is reasonable to assume that service is improving. Other types of information which offer possible aid in the evaluation of service are attendance figures, materials actually being read in the library at given times, reference questions unanswered and book requests not filled, and the number and nature of interlibrary loans. However, one should always be aware of the shortcomings and potential dangers of such statistical studies, and exercise proper caution. ${ }^{7}$

The prevailing teaching methods on a particular campus will bear directly upon the use of the library, and every effort should be made to advise faculty members of new acquisitions and to involve them in the selection of materials for purchase. As new courses or curricula are added, the librarian should be consulted early regarding the actual and potential significance of library resources in the areas under consideration. The effectiveness of instruction in the use of the library will normally be reflected in the extent and manner in which students make use of library materials and services.

It may also be advisable for the teaching faculty and the library staff to undertake joint studies of the library's program and resources. Such cooperative evaluations will tend to strengthen the relationship between classroom and library, and should be used as often as seems necessary. Occasionally it may be desirable to engage the services of specially qualified persons outside the institution in connection with such surveys.

\section{INTERLIBRARY COOPERATION}

The primary concern of the junior college librarian should be to provide the best possible service to the students and faculty of his institution. In order to do so, he should cooperate with the other institutions in the community and region to make the resources of all libraries available to the patrons of

7 The recent ARCL Monograph by Patricia B. Knapp, College Teaching and the College Library (ACRL Monograph No. 23; Chicago: ALA, 1959), demonstrates how enlightening results can be produced by a careful analysis of college library statistics. 
any particular library through interlibrary loan. Within the immediate region it may be possible to enter into cooperative arrangements with other libraries to avoid unnecessary duplication of materials and thus stretch the total dollar resources of the several libraries involved. However, it cannot be stressed too strongly that the two-year college library must be planned to give total service, and that other neighboring libraries must not be used to provide the books essential to the basic junior college program.
The two-year college in America is today rapidly changing and expanding. Eventually, it may well become an institution quite different from what it is at the present time. These standards, therefore, may require significant upward revision when the junior college reaches a new stage in its development. At that point, it may well need much larger and richer library resources and greatly extended services. Junior college librarians and administrators should be alert to this coming challenge.

\section{For Art Librarians}

\section{At the Montreal Conference}

ACRL's newest subdivision, its Art Subsection of the Subject Specialists Section, will have a full program during the Montreal Conference. The art librarians will meet for a dinner and business session beginning at 6:30 on the evening of Monday, June 20. On that same day they will hold a luncheon and plan visits to the Montreal Museum of Fine Arts and the École des Beaux-Arts de Montreal. On Tuesday, June 21, they will join the full Subject Specialists Section on its tour to Ottawa. The art librarians will have a special opportunity in Ottawa to visit libraries in the museums and galleries there. A highlight of the trip will be their visit to the National Gallery of Canada.

The subsection completed its organization during ALA's Midwinter Meeting with the official approval of the bylaws that had been adopted at the Washington Conference last summer. Present chairman of the subsection is Miss Phyllis A. Reinhardt of Smith College.

The following committee chairmen have been appointed by Miss Reinhardt: Miss Carol Selby, librarian of the Detroit Institute of Arts, chairman of the Committee on Indexing Museum Bulletins; Mr. Conrad H. Rawski, head of the Department of Fine Arts of the Cleveland Public Library, chairman of the Committee on Publication of Art Library Catalogs; Miss B. Adele Knepley, art librarian of the School of Fine arts of the University of Pennsylvania, chairman of the Nominating Committee; Miss Lucile Ouimet, librarian of the École des Beaux-Arts de Montréal, chairman of the Program Committee for the Montreal Conference; Mr. William J. Dane, principal art librarian of the art and music department of the Public Library of Newark, chairman of the Membership Committee; and Mrs. Jean R. Tomko, classics librarian of the Library of The Johns Hopkins University, is archivist for the subsection.

Membership in the subsection is open. ACRL members interested in membership should write directly to Mr. Dane or to Miss Reinhardt. 